This is the accepted version of article first published online by Springer in Small Business Economics on 19

September 2016, available at: http://link.springer.com/article/10.1007/s11187-016-9803-0

Accepted version downloaded from SOAS Research Online: http://eprints.soas.ac.uk/22968/

\title{
Does Foreign Direct Investment Stimulate New Firm Creation? In Search of Spillovers through Industrial and Geographical Linkages
}

\author{
Laixiang Sun \\ Department of Geographical Sciences \\ University of Maryland \\ Email: 1sun123@umd.edu \\ School of Finance and Management \\ SOAS University of London \\ Email: LS28@soas.ac.uk \\ International Institute for Applied Systems Analysis (IIASA) \\ Laxenburg, Austria \\ Email: $\underline{\text { Sun@iiasa.ac.at }}$ \\ In Hyeock Lee \\ Department of Management \\ Quinlan School of Business, Loyola University Chicago \\ E-mail: $\underline{\text { ilee1@luc.edu }}$
}

$\&$

Eunsuk Hong*

School of Finance and Management

SOAS University of London

Email: eh19@soas.ac.uk

* Corresponding author 
This is the accepted version of article first published online by Springer in Small Business Economics on 19

September 2016, available at: http://link.springer.com/article/10.1007/s11187-016-9803-0

Accepted version downloaded from SOAS Research Online: http://eprints.soas.ac.uk/22968/

\title{
Does Foreign Direct Investment Stimulate New Firm Creation? In Search of Spillovers through Industrial and Geographical Linkages
}

\begin{abstract}
This paper examines the spillover effects of inward foreign direct investment (FDI) on the entrepreneurial activities of new firm creation through both industrial and geographical linkages. Using a dataset of 44,434 newly created small firms in 234 regions of South Korea in 2000-2004, this study finds that while the spillover impacts of FDI in the low-tech industry are positive and significant across almost all four possible combinations of the intra-/inter-regional and intra/inter-sectoral channels, the impacts in the high-tech industry are largely intra-sectoral within the host region and across neighboring regions. Moreover, all statistically significant spillover effects follow an inverted 'U'-shaped curvilinear trend.
\end{abstract}

Key Words: Inward foreign direct investment; New firm creation; Entrepreneurship; Sectoral and Spatial Analysis.

JEL Classifications: F23, L26, M13, R12, 


\section{Introduction}

Foreign direct investment (FDI) has arguably become a distinguishing feature of the globalized economy in the two most recent decades. Global FDI inflows grew sixfold between 1990 and 2012 and the total stock of FDI rose elevenfold during the same period. ${ }^{1}$ The surge of FDI has stimulated great research efforts to investigate the effect of FDI presence on the strategic behavior and performance of domestic firms through the channel of productivity spillover (among others, Aitken and Harrison 1999; Altomonte and Pennings 2009; Buckley et al. 2006; Garcia et al. 2013; Haddad and Harrison 1993; Haskel et al. 2007; Motohashi and Yuan 2010). In contrast to the large body of literature on the productivity-spillover of FDI, there has been a limited research on the link between inward FDI and new firm creation in host countries.

There are several publications addressing the intra- and inter-sectoral spillover effects of inward FDI on the net entry or survival of domestic firms at the industry level (Ayyagari and Kosová 2010; Barbosa and Eiriz 2009; Burke et al. 2008; De Backer and Sleuwaegen 2003; Görg and Strobl 2002). In addition, Lee et al. (2014) examine the intra- and inter-regional spillover effects of inward FDI on the gross entry of local entrepreneurial firms in a given subnational region of a host country. While each of the industrial and geographic perspectives makes important contributions to the literature in its own right, there is a lack of research to examine the joint sectoral and spatial spillover effects of inward FDI on the activities of new firm creation by local entrepreneurs in a host country or regions. This paper intends to fill this

\footnotetext{
${ }^{1}$ In monetary term, global FDI inflows grew from US\$ 208 billion in 1990 to US\$ 1.3 trillion in 2012; the total stock rose from US\$ 2 trillion (equivalent to 7\% of world GDP) in 1990 to US\$23 trillion (equivalent to 32\% of world GDP) in 2012 (UNCTAD FDI Statistics; UNCTAD World Investment Report, 2013).
} 
Accepted version downloaded from SOAS Research Online: http://eprints.soas.ac.uk/22968/

important gap. In more detail, we aim to answer the empirical question of whether and to what extent inward FDI stimulates the creation of new firms in a host region when both parties are colocated in the proximate sectoral and/or geographic spaces in a host country.

To address joint sectoral and spatial spillover effects, we specify two (simultaneous) equations, one for the high-tech sector and the other for the low-tech sector. ${ }^{2}$ In more detail, we specify the density of newly created firms in the high-tech (low-tech) sector in the focal region as a function of: (i) the density of inward FDI projects in the high-tech (low-tech) sector in the focal region; (ii) the density of inward FDI projects in the low-tech (high-tech) sector in the focal region; (iii) the spatially weighted average density of inward FDI projects in the high-tech (lowtech) sector across neighboring regions of the focal region; (iv) the spatially weighted average density of inward FDI projects in the low-tech (high-tech) sector across neighboring regions of the focal region; and a comprehensive set of locational variables as controls. In this setting, coefficients of the first explanatory variable (i) capture the intra-sectoral and intra-regional spillover effects of FDI channeled through supplier-customer relations, labor similarity and technology similarity; coefficients of the second variable (ii) capture the inter-sectoral and intraregional spillover effects of FDI; coefficients of the third variable (iii) capture the intra-sectoral

\footnotetext{
${ }^{2}$ Assessing the joint sectoral and spatial spillover effects is challenging. For example, catching the upstream to downstream supplier-customer relationship across regions typically involves multi-regional input-output tables. Measuring and analyzing labor similarity and technical similarity across industries (Jofre-Monseny et al. 2011; Marshall 1890) and regions would involve multi-industrial and multi-regional matrices more complicated than multi-regional input-output tables. To avoid complicated big matrices without compromising our research mission, we focus on the high-tech and low-tech sub-sectors in the manufacturing industry. Such a high-tech versus low-tech dichotomy would make the issue of spillover from labor similarity and technology similarity largely an intraindustrial affair within the focal region and across neighboring regions.
} 
and inter-regional spillover effects of FDI; and coefficients of the forth variable (iv) capture the inter-sectoral and inter-regional spillover effects of FDI, respectively.

We utilize the data from the Republic of Korea (hereafter Korea) to quantify the spillover effect of inward FDI across sectors and spaces on new firm creation during the period of 20002004. We chose the years 2000-2004 in our current study for the following three reasons. First, after the severe Asian Financial Crisis that devastated Korean economy in 1997-1999, the Korean government made two major policy shifts to revive the health of its national economic system under the restructuring programs guided by the International Monetary Fund (IMF). One was the transition from a development strategy heavily relying on foreign loans to one favoring inward FDI with the aim to attract and retain the advanced technologies associated with FDI. For attracting FDI, such proactive incentive packages as provision of preferential tax treatment and construction of industrial complex for manufacturing FDI were initiated (Korea, MOCIE, 2003). As a result, Korea was able to attract US\$ 60 billion from capable foreign investors as inward FDI projects during the period of 1998 - 2003, an amount which was more than double the 36 year total of US\$24.6 billion over 1961-1997 (Korea, MOCIE, 2003). This remarkable accomplishment enabled the country to recover its status as one of the top four foreign exchange reserving nations in the world, and to graduate the bailout programs of IMF sooner than scheduled (Kim \& Hwang, 2000; Athukorala, 2003; Nicolas, 2003). The other was the formulation and implementation of strong incentive packages to help prospective entrepreneurs create small but knowledge-intensive and innovative new ventures during the tech booming period so as to strengthen the innovative ability of the economy and overcome the vulnerability caused by an over-dependence on large Korean conglomerates called chaebols. These two 
developments provide excellent opportunities for researchers to investigate plausible connections between inward FDI and the activities of new firm creation by indigenous entrepreneurs. Second, the Korean government amended the Korean Standard Industrial Classification (Korean SIC) Code as of January 2000. Third, the full population data of new firm start-ups created in Korea are available until the year of 2004. As such, the 2000-2004 time period provides the best available data on new firm creation activities in Korea with consistent sectoral coverage.

The natural input-output connections between the high-tech and low-tech sectors mean that the two equations presented above are interdependent. This interdependency is confirmed by the high value of the correlation coefficient between the two dependent variables, which stands at 0.81 (see Table 2 for the full correlation matrix). This means that the standard equation-byequation regression with the ordinary least square (OLS) estimator would generate distorted results. To address this interdependency issue, we specify these two equations as a simultaneous equations system, meaning that the two dependent variables are jointly dependent and each should enter the right-hand-side of the other equation (Greene 2008, Chapter 15). Technical details of the estimation methods will be presented in Section 3 and the estimation results will be reported in Section 4, following the discussions on the theoretical foundations of industrial and geographical linkages of FDI spillovers and competition effects of FDI in Section 2.

This research makes several contributions to the literature on regional science, entrepreneurship, and international business studies. First, it represents one of the first attempts to investigate the joint sectoral and spatial explanations for the creation of indigenous firms stimulated by inward FDI. It enriches our theoretical understanding of the cause-effect connections between international factors (e.g., inward FDI) and domestic entrepreneurship 
This is the accepted version of article first published online by Springer in Small Business Economics on 19 September 2016, available at: http://link.springer.com/article/10.1007/s11187-016-9803-0

Accepted version downloaded from SOAS Research Online: http://eprints.soas.ac.uk/22968/

phenomenon (e.g., creation of indigenous firms), specifically in terms of geographic proximity

and industrial value-chain and technology linkage. Second, it demonstrates an effective empirical approach for assessing the potential impact of inward FDI on new firm creation by uncovering FDI spillover effects within and across regions/sectors. In this way, it quantifies to what extent the different combinations of the intra-/inter-sectoral and intra-/inter-regional FDI spillovers affect new firm creation in a host country. Third, its findings may have important implications for the location strategy of firms and for regional economic development. Because both the sectoral and spatial proximities between FDI activities and entrepreneurial initiatives are important engines for fostering firm creation activities which sequentially generate new jobs and wealth in the locality, mechanisms facilitating entrepreneurship through easy access to FDI activities within the host and proximate geographical regions and closely related industrial sectors would promote economic growth and development in the region.

\section{Theoretical background}

As discussed earlier, foreign-owned MNEs are generally deemed as being more efficient than indigenous firms in host countries. This is mainly because MNEs possess superior knowledgebased firm-specific advantages to effectively overcome the social and economic obstacles associated with foreign market entry (Caves 1974, 1996; Zaheer 1995; Buckley, Clegg and Wang, 2006 2007). As such, MNEs implementing FDI projects usually act as knowledge and information providers to indigenous entrepreneurs in the host countries (OECD 2000). We argue that the close proximity between the sources and beneficiaries of FDI spillovers in terms of both 
This is the accepted version of article first published online by Springer in Small Business Economics on 19 September 2016, available at: http://link.springer.com/article/10.1007/s11187-016-9803-0

Accepted version downloaded from SOAS Research Online: http://eprints.soas.ac.uk/22968/

industrial sectors and geographical spaces is critical for materializing the potential stimulating effect of FDI on new firm creation.

\section{[Figure 1 goes about here]}

Figure 1 presents the major channels of inward FDI spillovers on prospective entrepreneurs in a host country. It indicates that inward FDI implemented in a host region generally affects the firm creation activities of indigenous entrepreneurs through both industrial linkages and geographical proximities. On one hand, indigenous entrepreneurs' new firm creation may be spurred by inward FDI projects in the same industrial sector as well as those in other sectors (i.e., Sectoral Spillovers). The theory of agglomeration economics posits that knowledge spillovers are facilitated among local participants through industrial relations (Marshall, 1890; Jofre-Monseny et al. 2011), which may depend on whether knowledge providers and recipients belong to the same or neighboring social groups (Blau, 1977; McPherson and Smith-Lovin, 1987; Sorenson and Stuart, 2001). The former effects are called 'intra-sectoral' spillovers, and the latter 'inter-sectoral' spillovers.

Together with the sectoral spillovers, indigenous entrepreneurs' founding activities may be stimulated by various inward FDI projects located not only in the same region, but also in the neighboring regions (i.e., Spatial Spillovers). These channels are emphasized by the localization theory of entrepreneurship (Acs et al. 2013; Audretsch and Feldman 2004; Audretsch et al. 2005; Stuart and Sorenson 2003; Von Hipple 1994). The localization theory argues whether knowledge providers and recipients belong to the same or close neighboring geographic regions is critical in facilitating new firm creation activities. The former relationships are 'intra-regional' whereas the latter ones are 'inter-regional'. 


\subsection{The industrial channels of FDI spillovers}

According to the social distance argument, the accumulation of common experience can be made possible only when participants interact with each other in the same or closely linked social groups including industrial sectors (Blau, 1977; McPherson and Smith-Lovin, 1987; Sorenson and Stuart, 2001). The absorptive capacity argument also supports this view: firms' ability to recognize new business opportunities depends on their prior knowledge (Cohen and Levinthal 1990; Rothaermel and Thursby 2005; Gilbert, McDougall and Audretsch 2008), and the prior knowledge resulting in new firms can be best accumulated by prospective entrepreneurs' prior experiences that are formulated through repeated and close interactions with knowledge providers of similar socio-demographic attributes and interests in the same or similar sectoral environments (Sorenson and Stuart 2001). As a result, when both MNEs implementing inward FDI projects and their prospective entrepreneurial counterparts are to be operating in the same or closely related industrial sectors, it would be more conducive for prospective entrepreneurs to learn from MNEs. In addition, it is more likely that foreign-owned MNEs build both backward and forward linkages with indigenous entrepreneurs when both are operating within closely related sectors than across heterogeneous unrelated sectors.

Intra-industrial relations have been the base for identifying the sources of agglomeration economics (Jofre-Monseny et al. 2011). Marshall (1890) highlights three mechanisms that drive entrepreneurs and firms to co-locate industrially in a geographic region. They are labor market pooling, input sharing, and knowledge spillovers. Labor market pooling refers to the advantage that firms and workers obtain from locating in a thick market. A densely-populated local labor 
This is the accepted version of article first published online by Springer in Small Business Economics on 19 September 2016, available at: http://link.springer.com/article/10.1007/s11187-016-9803-0

Accepted version downloaded from SOAS Research Online: http://eprints.soas.ac.uk/22968/

market in a given industry would lead to higher mobility of workers across firms in the industry and thus availability of experienced workers for the new firm which operates in the same industry. This intra-industrial labor mobility argument can be easily extended to an interindustrial argument with potentially reduced effect in line with the reduced extent of industrial connection and labor similarity. Input sharing denotes the customer-supplier relations and a popular quantitative characterization of such relation is given by Input-Output (IO) tables in a given region (a regional IO table) or across regions (multi-regional IO tables plus inter-regional trade matrix).

When we adopt a high-tech versus low-tech dichotomy in the manufacturing industry, it is well-acknowledged in the literature of industry studies that in comparison with its low-tech counterpart, high-tech manufacturing is dominated by firms that rely on new technology, highly skilled personnel, and high levels of R\&D activities to compete (Helmers and Rogers 2011; Kirner et al. 2009; Nunes et al. 2011; Thornhill 2006). High-tech manufacturing places stronger emphasis on new product development, advertising, customer service, and entrepreneurial strategic postures than its low-tech counterpart does, resulting in differentiation strategies coupled with premium pricing instead of cost leadership strategies that are prevalent in the lowtech sectors (Berry and Taggart 1998; Covin et al. 1990). Following the perspectives of labor similarity and technology similarity, it is natural to expect that the spillover effects of FDIfunded high-tech manufacturing operations on the firm creation activities in the host market are stronger when the new firms operate in the same high-tech sector than in the relatively remote low-tech sector. 
Although the above discussion implies that the impact of FDI spillovers on new firm creation is largely an intra-sectoral affair in the high-tech sector, we would be able to expect that FDI operations in the high-tech sector exert strong positive spillover effects on new firm creation activities in the low-tech sector through backward and forward linkages between the two sectors. For example, the entries of FDI operations increase demand for intermediate inputs produced by upstream firms in the low-tech sector and this would induce entries of new firms in the sector. It is possible for FDI operations in the low-tech sector to have spillover effects on new firm creation activities in the high-tech sector in consideration of the supplier-customer linkages; however, the extent of the effect would be moderate at best. In a similar logic, one can argue that the improved access to new, higher quality or less costly equipment and intermediate inputs produced by FDI firms in the high-tech sector would induce entries of domestic customer firms in the low-tech sector. Furthermore, as argued in Blalock and Gertler (2008) and Javorcik (2004), while FDI firms have an incentive to prevent technology spillovers that will enhance competitiveness of their domestic rivals in the same sector, they often benefit from cooperative arrangements that transfer knowledge to multiple upstream domestic suppliers and downstream domestic customers. Technology transfer to multiple suppliers will help to avoid the holdup problems, induce entry, generate competition among input suppliers, improve input quality, lower prices, and benefit all downstream firms and their multinational clients (Clark and Highfill 2011). In contrast, for new firm creation in the low-tech sectors, the positive intra-industrial effect of FDI spillovers as suggested by the perspectives of labor and technology similarities could be partially or even fully offset by the negative effect of increased competition in the same 
This is the accepted version of article first published online by Springer in Small Business Economics on 19 September 2016, available at: http://link.springer.com/article/10.1007/s11187-016-9803-0

Accepted version downloaded from SOAS Research Online: http://eprints.soas.ac.uk/22968/

sector, resulting in reduced opportunities and increased costs for the entry of domestic entrepreneurial firms, as will be further discussed in Section 2.3.

\subsection{The geographical channels of FDI spillovers}

Strong existing customer-supplier relations across industries would facilitate new firm creation when input suppliers and customers are readily available in a given region and its close neighboring regions. Knowledge spillover mechanism also indicates that knowledge and ideas flow more easily between firms and employees located nearby in geographical proximity. As such, it is worth highlighting that both labor pooling and input sharing mechanisms may effectively facilitate knowledge spillovers in locality.

The localization theory of knowledge spillovers posits that sticky knowledge is essential in a successful commercialization process of new and entrepreneurial ideas, and that such a knowledge possesses highly localized characteristics in geographic proximity (Acs et al. 2013; Audretsch and Feldman 2004; Audretsch et al. 2005; Stuart and Sorenson 2003; Von Hipple 1994). This means that, when knowledge recipients (i.e., indigenous entrepreneurs in this research) are located in proximity to knowledge providers (i.e., inward FDI by MNEs) within the same region or near neighboring regions, it helps the prospective entrepreneurs exploit the knowledge from MNE operations more easily and thus facilitating their firm creation activities. On the other hand, it provides convenience for MNE operations to build backward and forward networks with indigenous entrepreneurial firms. Sticky local knowledge may spill over to recipients in more remote regions (Audretsch and Feldman 2004; Audretsch and Keilbach 2007), but we expect that the net spillover effects of inward FDI on new firm creation are stronger when 
This is the accepted version of article first published online by Springer in Small Business Economics on 19 September 2016, available at: http://link.springer.com/article/10.1007/s11187-016-9803-0

Accepted version downloaded from SOAS Research Online: http://eprints.soas.ac.uk/22968/

both are in close geographical proximity, because the cost of transferring sticky knowledge from the providers to the recipients usually rises as the geographic distance between the two parties increases (Audretsch and Feldman 2004; Audretsch and Lehmann 2005; Audretsch et al. 2005).

\subsection{Competition effects of FDI}

While the above discussed agglomeration and spillover effects are beneficial to the entrepreneurial firm creation, the opposite side of the same coin is competition effects which exert negative influence on the firm creation activities. Generally speaking, a firm is simultaneously a source of knowledge spillovers and a source of competition to other firms in the same or proximate industry and region, and therefore what we can observe is the net of positive spillover benefits minus negative competition effects. With regard to FDI operations, because foreign-owned MNEs usually provide the host market with products of higher quality and/or at lower prices than indigenous counterparts commonly do, the presence of FDI firms in the host market increases the level of market competition (Barbosa and Eiriz 2009; Barrios et al. 2005; Buckley et al. 2007; De Backer and Sleuwaegen 2003). The increased competition may consequently act as an entry barrier for indigenous entrepreneurs to launch new businesses (Aitken and Harrison 1999; Ayyagari and Kosová 2010; Haddad and Harrison 1993). FDI firms typically poach for better staff by offering higher pay and attractive career development, which results in a shrinking pool of prospective entrepreneurs in the host market (De Backer and Sleuwaegen 2003). Furthermore, the increasing presence of FDI operations in the host market may lead to rising congestion costs that further constrain the firm creation activities of local entrepreneurs (Folta et al. 2006). Lee et al. (2014) find that when the level of FDI presence is 
This is the accepted version of article first published online by Springer in Small Business Economics on 19 September 2016, available at: http://link.springer.com/article/10.1007/s11187-016-9803-0

Accepted version downloaded from SOAS Research Online: http://eprints.soas.ac.uk/22968/

low, the competition is moderate and the effects of agglomeration and spillovers are more likely to dominate; nevertheless, along with the rise in the level of FDI presence, the negative competition effects would gradually increase and become dominant after the level of FDI presence passes a certain threshold. This suggests an inverted ' $U$ '-shaped relationship between the density of inward FDI-funded operations and the density of indigenous entrepreneurs' new firm creation activities in each of the four combinations of the intra-/inter-sectoral and intra/inter-regional FDI spillover channels.

\section{Model specification and estimation methods}

\subsection{Model Specification}

To investigate the spillover effects of inward foreign direct investment (FDI) on the variation in new firm creations across high- versus low-technology industrial sectors and geographic regions, we specify the following two equations: one for new firm creation in the high-tech sector and the other for new firm creation in the low-tech sector. Due to the natural input-output connections between the two sectors, we treat these two equations as a simultaneous equations system.

$$
\begin{aligned}
& \left(\text { NewFirm }_{\text {Hight-Tech }}\right)_{i t}=\beta_{0}^{1}+\beta_{1}^{1}\left(\text { NewFirm }_{\text {Low-Tech }}\right)_{i t}+\gamma_{1} \cdot(\text { Sectoal } \& \text { Spatial FDISpillover Variables })_{i, t-1} \\
& \quad+\boldsymbol{\delta}_{1} \cdot(\text { Location Variables })_{i, t-1}+\alpha_{i}^{1}+\alpha_{t}^{1}+\varepsilon_{i t}^{1},
\end{aligned}
$$

$\left(\text { NewFirm }_{\text {Low-Tech }}\right)_{i t}=\beta_{0}^{2}+\beta_{1}^{2}\left(\text { NewFirm }_{\text {High-Tech }}\right)_{i t}+\boldsymbol{\gamma}_{2} \cdot(\text { Sectoal \& Spatial FDISpillover Variables })_{i, t-1}$ $+\boldsymbol{\delta}_{2} \cdot(\text { Location Variables })_{i, t-1}+\alpha_{i}^{2}+\alpha_{t}^{2}+\varepsilon_{i t}^{2}$. 
Accepted version downloaded from SOAS Research Online: http://eprints.soas.ac.uk/22968/

The two dependent variables are the density of local entrepreneurial firms in the hightech sector and low-tech sector, respectively, in region $i$ and year $t$, denoted as $\left(\text { NewFirm }_{\text {High-Tech }}\right)_{\text {it }}$ and $\left(\right.$ NewFirm Low-Tech $_{i t}$. The former (the latter) is measured as the ratios of the number of entrepreneurial firms in the high-tech (low-tech) sector created in region $i$ and year $t$ to the national total number of entrepreneurial firms created in year $t$. The measurement is presented in percentage terms. Local entrepreneurial firms are defined as newly created small firms with 200 or less employees (Brush and Vanderwerf 1992; Zahra et al. 2000). We obtained the full population data of new firm start-ups located in 234 sub-national regions of Korea between 2000 and 2004 from the Factory Establishment and Management Information System (FEMIS) database of manufacturing industries (http://www.femis.go.kr/), compiled by the Korean Ministry of Trade, Industry \& Energy. For the five-year period of 2000-2004, there were in total 58,564 manufacturing firms registered in Korea, of which 44,434 firms are qualified as domestic entrepreneurial firms for this research. We follow the five-digit Korean SIC codes and the guidelines suggested by the Organization for Economic Co-operation \& Development (OECD) STI committee and the Korea Institute of Economics \& Trade (KIET) to divide the full sample into the high-tech and low-tech sub-samples. ${ }^{3}$ Because the two variables are defined at the regional level, we obtain a total number of 1,170 region-year observations (234 sub-national regions $\times 5$ years). We have to exclude 4 observations with missing values for some location

\footnotetext{
${ }^{3}$ The high-tech sub-sample includes new firms operating in the following industries: biotechnology; the environment; alternative energy; semi-conductor equipment and electronic components; audio and video; telecommunication equipment, computers and auxiliary devices; medical equipment; precise mechanics; optical; and sophisticated parts and materials. The low-tech sub-sample includes firms in all other remaining manufacturing industries.
} 
This is the accepted version of article first published online by Springer in Small Business Economics on 19 September 2016, available at: http://link.springer.com/article/10.1007/s11187-016-9803-0

Accepted version downloaded from SOAS Research Online: http://eprints.soas.ac.uk/22968/

control variables. As a result, the final dataset is an unbalanced panel with 1,166 observations.

The vector 'Sectoral \& Spatial FDI Spillover Variables' captures the major channels of sectoral and spatial FDI spillovers as sketched in Figure 1. The vector 'Location Variables' captures the standard regional determinants of the new firm creations. The disturbance terms consist of the unobserved regional fixed effect that is constant over time $\left(\alpha_{i}\right)$, the unobserved time effect that is common for all regions $\left(\alpha_{t}\right)$, and the transitory errors $\left(\varepsilon_{i t}\right)$ that may vary across regions and over time with a zero mean value.

\subsection{Sectoral and spatial FDI spillover variables}

'Sectoral \& Spatial FDI Spillover Variables' in equations (1) and (2) represent the four channels of joint sectoral and spatial FDI spillovers as captured in Figure 1: (a) intra-regional and intrasectoral, (b) intra-regional and inter-sectoral, (c) inter-regional and intra-sectoral, and (d) interregional and inter-sectoral. To operationalize these four channels in an econometric model, we construct the following set of variables.

The first two key variables are the density of FDI projects in the high-tech sector and low-tech sector, respectively, in region $i$ and year $t-1$, denoted as $\left(F D I_{\text {High-Tech }}\right)_{i, t-1}$ and $\left(F D I_{\text {Low-Tech }}\right)_{i, t-1}$. The former (the latter) is measured as the ratios of the number of FDI projects in the high-tech (low-tech) sector located in region $i$ and implemented in year $t-1$ to the national 
Accepted version downloaded from SOAS Research Online: http://eprints.soas.ac.uk/22968/

total number of FDI projects implemented in the same year. ${ }^{4}$ The measurement is also presented in percentage terms. These two variables would serve the purpose of capturing the effects of intra- and inter-sectoral spillovers of FDI in a given region. We construct these two FDI spillover variables using the full population data of 1,278 inward FDI projects located in 234 sub-national regions of Korea between 1999 and 2003. The data are obtained from the Investment Notification Statistics Center (INSC) database (http://mgr.kisc.org/insc/), compiled by the Korean Ministry of Trade, Industry \& Energy.

To capture inter-regional effect of FDI spillovers, we employ a 234×234 rowstandardized first-order contiguity spatial weight matrix $(\mathbf{W})$. The cell $(i, j)$ in $\mathbf{W}$ has value 1 if regions $i$ and $j$ are next-door neighbors, and value zero otherwise. By convention, zeros are placed on the main diagonal of the $\mathbf{W}$ matrix. Because we consider inter-regional relationships across 234 sub-national regions in Korea, $\mathbf{W}$ is a $234 \times 234$ matrix. The row-standardization of the $\mathbf{W}$ matrix means a row-normalization so that the row-sums add to unity. With the assistance of $\mathbf{W}$, we construct the contiguity-weighted average density of inward FDI projects in the hightech sector and low-tech sector, respectively, in the neighboring regions that share some common borders with region $i$ for each year $t-1$, denoted as $\left(\mathbf{W} \cdot F D I_{H i g h-T e c h}\right)_{i, t-1}$ and $\left(\mathbf{W} \cdot F D I_{\text {Low-Tech }}\right)_{i, t-1}$.

To capture the inverted ' $U$ '-shaped curvilinear relationship between each of the above four sectoral and spatial FDI spillover variables and each of the two dependent variables as discussed in Section 3.1, the squared terms of the above four variables, i.e., $\left(F D I_{H i g h-T e c h}^{2}\right)_{i, t-1}$,

\footnotetext{
${ }^{4}$ The adoption of a one-year lag is a natural accommodation to the fact that FDI spillovers would take time and furthermore, such adoption of a time-lag for independent variables is also popular in the literature (e.g., among others, Fritsch and Falck 2007; Sutaria and Hicks 2004).
} 
Accepted version downloaded from SOAS Research Online: http://eprints.soas.ac.uk/22968/

$\left(F D I_{\text {Low-Tech }}^{2}\right)_{i, t-1},\left(\mathbf{W} \cdot F D I_{H i g h-T e c h}^{2}\right)_{i, t-1}$ and $\left(\mathbf{W} \cdot F D I_{\text {Low-Tech }}^{2}\right)_{i, t-1}$, should also enter each regression equation.

By incorporating these operational variables which represent the four channels of sectoral and spatial FDI spillovers, Equations (1) and (2) can be reformulated as follows:

$$
\begin{aligned}
& \left(\text { NewFirm }_{\text {Hight-Tech }}\right)_{i t}=\beta_{0}^{1}+\beta_{1}^{1}\left(\text { NewFirm }_{\text {Low-Tech }}\right)_{i t}+\beta_{2}^{1}\left(F D I_{\text {High-Tech }}\right)_{i, t-1}+\beta_{3}^{1}\left(F D I_{\text {High-Tech }}^{2}\right)_{i, t-1} \\
& +\beta_{4}^{1}\left(F D I_{\text {Low-Tech }}\right)_{i, t-1}+\beta_{5}^{1}\left(F D I_{\text {Low-Tech }}^{2}\right)+\beta_{6}^{1}\left(W \cdot F D I_{H i g h-T e c h}\right)_{i, t-1}+\beta_{7}^{1}\left(W \cdot F D I_{H i g h-T e c h}^{2}\right)_{i, t-1} \\
& +\beta_{8}^{1}\left(W \cdot F D I_{\text {Low-Tech }}\right)_{i, t-1}+\beta_{9}^{1}\left(W \cdot F D I_{\text {Low-Tech }}^{2}\right)_{i, t-1}+\boldsymbol{\delta}_{1} \cdot(\text { Location Variables })_{i, t-1} \\
& +\alpha_{i}^{1}+\alpha_{t}^{1}+\varepsilon_{i t}^{1} \\
& \left(\text { NewFirm }_{\text {Low-Tech }}\right)_{i t}=\beta_{0}^{2}+\beta_{1}^{2}\left(\text { NewFirm }_{\text {High-Tech }}\right)_{i t}+\beta_{2}^{2}\left(F D I_{\text {High-Tech }}\right)_{i, t-1}+\beta_{3}^{2}\left(F D I_{H i g h-T e c h}^{2}\right)_{i, t-1} \\
& +\beta_{4}^{2}\left(F D I_{\text {Low-Tech }}\right)_{i, t-1}+\beta_{5}^{2}\left(F D I_{\text {Low-Tech }}^{2}\right)+\beta_{6}^{2}\left(W \cdot F D I_{\text {High-Tech }}\right)_{i, t-1}+\beta_{7}^{2}\left(W \cdot F D I_{\text {High-Tech }}^{2}\right)_{i, t-1} \\
& +\beta_{8}^{2}\left(W \cdot F D I_{\text {Low-Tech }}\right)_{i, t-1}+\beta_{9}^{2}\left(W \cdot F D I_{\text {Low-Tech }}^{2}\right)_{i, t-1}+\boldsymbol{\delta}_{2} \cdot(\text { Location Variables })_{i, t-1} \\
& +\alpha_{i}^{2}+\alpha_{t}^{2}+\varepsilon_{i t}^{2} \text {. }
\end{aligned}
$$

\subsection{Location variables}

'Location Variables' represent major determinants of new firm creation and location choice identified in the existing literature. Data for constructing our 'Location Variables' are from the regional statistics of the Korean National Statistics Office (http://kosis.nso.go.kr/). In line with the time-lag adopted for the 'Sectoral \& Spatial FDI Spillover Variables', we use a one-year lag for each of the location variables to accommodate the time-consumed between assessing available information and making the decision to establish a new firm. 
Accepted version downloaded from SOAS Research Online: http://eprints.soas.ac.uk/22968/

The local market size of each region is arguably the most important location force and we capture it by two variables. The first is the gross regional product per capita [in million KRW (South Korean Won), US\$1 = 1,188.75 KRW as of May 19, 2016] from manufacturing firms in region $i$ and year $t-1$ and denoted as $G R P P C_{i, t-1}$, which captures the variation in per capita income across regions and over time. The second is total population in region $i$ and year $t-1$ and denoted as $\mathrm{POP}_{i, t-1}$. Please note that for this research it is important to have a clear distinction between the effects of per capita income and of population size in the regional economy, because it is well-recognized in the trade literature that given two economies with similar total market size, as captured by total Gross Domestic Production (GDP), a less populous and richer economy will be more conducive to innovations and high-tech firm creation than a more populous and poorer economy (Linder 1961; Murphy et al. 1989; Ramezzana 2000).

The third location variable is the level of local wage (Fritsch and Falck 2007), which is measured by monthly average wage per employee in region $i$ and year $t-1$, denoted as Wage $_{i, t-1}$. Because cheap labor forces are key resources for labor-intensive manufacturing, local wage rates would be negatively correlated to the level of firm creation activities in the low-tech sector in particular. More generally, rising wage rates would increase the opportunity costs of selfemployment and the cost of hiring workers, and therefore, exerting a negative impact on firm creation activities in both sectors. However, it is worth noting that a positive relationship might be possible between the local wage rate and the level of firm creation activities in the high-tech sector, because a high wage rate may signal the high quality of human capital in the region (Zucker et al. 1998). 
The fourth location variable is the size of land available $\left(\mathrm{in} \mathrm{km}^{2}\right.$ ) for building factories (Woodward 1992) in region $i$ and year $t-1$ and denote this variable as LandSize $_{i, t-1}$. It is intuitive and obvious that the most important precondition for building a manufacturing factory is the availability of land, which is subject to strict urban development zoning policy in the case of Korea. In addition, employing this variable as a control factor has the advantage of capturing the zoning-induced phenomenon that new entrepreneurs can overcome the constraints of land unavailability in their home regions by operating their own firms in other regions. Consequently, we expect a positive effect of this variable on new firm creation because increased land size for building factories would bring in potential sites for new firm creation.

The fifth location variable is the variation in regional tax level, which is proxied by the per capita total tax revenue of the local government in region $i$ and year $t-1$ and denoted as $T A X P C_{i, t-1}$. On the one hand, a higher level of local tax revenue would enable the local government to provide better infrastructure and other public services which are conducive to new firm creation. On the other hand, it is acknowledged in the literature that increases in effective business tax burdens in a jurisdiction decrease entry rates of new firms to the jurisdiction and such negative effects are strongest in industries characterized by higher relative profitability or value-added margin (Kneller and McGowan 2012; Papke 1991). Therefore, we may expect that the net effects of $T A X P C_{i, t-1}$ on the high-tech and low-tech sectors are different.

In our regression equations, we take natural logarithm of all above location variables to reduce skewness. We also include local industrial complex dummies (ICD), which indicate the existence of one or more industrial complex established by the local government with the aim to increase the attractiveness of the region to both new and old firms, and control for regional and 
Accepted version downloaded from SOAS Research Online: http://eprints.soas.ac.uk/22968/

yearly fixed effects to capture local initiatives in industrial policies and unobserved year-specific characteristics, respectively. The final specification of the simultaneous equations system is as follows:

$$
\begin{aligned}
& \left(\text { NewFirm }_{\text {Hight-Tech }}\right)_{i t}=\beta_{0}^{1}+\beta_{1}^{1}\left(\text { NewFirm }_{\text {Low-Tech }}\right)_{i t}+\beta_{2}^{1}\left(F D I_{\text {High-Tech }}\right)_{i, t-1}+\beta_{3}^{1}\left(F D I_{\text {High-Tech }}^{2}\right)_{i, t-1} \\
& \quad+\beta_{4}^{1}\left(F D I_{\text {Low-Tech }}\right)_{i, t-1}+\beta_{5}^{1}\left(F D I_{\text {Low-Tech }}^{2}\right)+\beta_{6}^{1}\left(W \cdot F D I_{\text {High-Tech }}\right)_{i, t-1}+\beta_{7}^{1}\left(W \cdot F D I_{\text {High-Tech }}^{2}\right)_{i, t-1} \\
& \quad+\beta_{8}^{1}\left(W \cdot F D I_{\text {Low-Tech }}\right)_{i, t-1}+\beta_{9}^{1}\left(W \cdot F D I_{\text {Low-Tech }}^{2}\right)_{i, t-1}+\beta_{10}^{1} \ln G R P P C_{i, t-1}+\beta_{11}^{1} \ln \text { Wage }_{i, t-1} \\
& \quad+\beta_{12}^{1} \ln \text { LandSize }_{i, t-1}+\beta_{13}^{1} \ln \text { TAXPC }_{i, t-1}+I C D_{i t}+\alpha_{i}^{1}+\alpha_{t}^{1}+\varepsilon_{i t}^{1},
\end{aligned}
$$

$$
\begin{aligned}
& \left(\text { NewFirm }_{\text {Low-Tech }}\right)_{i t}=\beta_{0}^{2}+\beta_{1}^{2}\left(\text { NewFirm }_{\text {High-Tech }}\right)_{i t}+\beta_{2}^{2}\left(F D I_{\text {High-Tech }}\right)_{i, t-1}+\beta_{3}^{2}\left(F D I_{H i g h-T e c h}^{2}\right)_{i, t-1} \\
& \quad+\beta_{4}^{2}\left(F D I_{\text {Low-Tech }}\right)_{i, t-1}+\beta_{5}^{2}\left(F D I_{\text {Low-Tech }}^{2}\right)+\beta_{6}^{2}\left(W \cdot F D I_{\text {High-Tech }}\right)_{i, t-1}+\beta_{7}^{2}\left(W \cdot F D I_{H i g h-T e c h}^{2}\right)_{i, t-1} \\
& \quad+\beta_{8}^{2}\left(W \cdot F D I_{\text {Low }_{\text {Tech }}}\right)_{i, t-1}+\beta_{9}^{2}\left(W \cdot F D I_{\text {Low-Tech }}^{2}\right)_{i, t-1}+\beta_{10}^{2} \ln \operatorname{GRPC}_{i, t-1}+\beta_{11}^{2} \ln \text { Wage }_{i, t-1} \\
& \quad+\beta_{12}^{2} \ln \text { LandSize }_{i, t-1}+\beta_{13}^{2} \ln P O P_{i, t-1}+I C D_{i t}+\alpha_{i}^{2}+\alpha_{t}^{2}+\varepsilon_{i t}^{2} .
\end{aligned}
$$

As discussed in Section 2 and above, we would expect $\beta_{1}^{1}, \beta_{1}^{2}, \beta_{2}^{1}, \beta_{2}^{2}, \beta_{4}^{1}, \beta_{4}^{2}, \beta_{6}^{1}, \beta_{6}^{2}$, $\beta_{8}^{1}, \beta_{8}^{2}, \beta_{12}^{1}$, and $\beta_{12}^{2}$ to be positive; and $\beta_{3}^{1}, \beta_{3}^{2}, \beta_{5}^{1}, \beta_{5}^{2}, \beta_{7}^{1}, \beta_{7}^{2}, \beta_{9}^{1}$, and $\beta_{9}^{2}$ to be negative. Table 1 summarizes the expected sign of each coefficient, including coefficients of other location variables.

\section{[Table 1 goes about here]}

\subsection{Estimation method}

As discussed in the introduction, the input-output linkages between the two sectors mean that the two equations presented above are interdependent and should be treated as a simultaneous 
equations system. Indeed, in Equations (5) and (6), the two dependent variables are interdependent and each enters the right-hand-side of the other equation. Several methods are available for estimating the simultaneous equations system we have specified. The easy one is equation-by-equation two-stage least square (2SLS) estimation using instrumental variable (IV) techniques. 2SLS would yield consistent estimates, but efficiency is not attained because crossequation error-term correlations are neglected. We estimate our equation system using threestage least squares (3SLS) because it combines the features of instrumental variables (IV) and general least square (GLS) estimators. In more detail, 3SLS procedure achieves consistency through appropriate instrumentation and efficiency through optimal weighting; it allows crossequation error correlations to differ from zero and its flexibility in the error covariance matrix allows for a substantial efficiency gain relative to estimating each equation separately with 2SLS (Green 2008, Chap. 15).

To satisfy the order condition for identification in the 3SLS full system estimation, we identify that the variable $\ln T A X P C_{i, t-1}$ in equation (5) would exert more significant impact on the activities of new firm creation in the high-tech sector than in the low-tech sector because the former is typically characterized by a higher value-added margin than the latter, as suggested in the literature (Kneller and McGowan 2012; Papke 1991). In contrast, we identify that the population variable $\ln P O P_{i, t-1}$ in equation (6) would have a more considerable impact on new firm creations in the low-tech sector than in the high-tech sector because the population size is more directly associated with demand for goods characterized by lower income-elasticities and with the supply of cheap labor force. 
Accepted version downloaded from SOAS Research Online: http://eprints.soas.ac.uk/22968/

To make the instrumental values as similar as possible to their observed values so as to further improve the consistency and efficiency of the 3SLS estimation, we introduce two instrumental variables as exogenous to the simultaneous equations system, meaning that they will appear only in the first stage of the 3SLS estimation. These two variables are land price and scale of agglomeration. ${ }^{5}$ Land price variable is proxied by the average amount of rent collected (in million KRW) per square-meter of commercial land in region $i$ and year $t-1$ and denoted as LandPrice $_{i, t-1}$. In comparison with large established firms, small firms are typically constrained by initial resource disadvantages and more sensitive to the land cost of establishing a new firm in making their location choices, and therefore, we expect a negative relationship between land price and the activities of new firm creation. The scale of agglomeration is proxied by the total number of firms operating in both manufacturing and service sectors in region $i$ and year $t-1$ and denoted as Agglomeration ${ }_{i, t-1}$. On the one hand, the presence of a larger number of firms in a region would generate positive agglomeration effects owing to the availability of closer spatial and inter-industry linkages, the accumulation of production factors, and the spillovers of technology (Bhat et al. 2014). On the other hand, many firms crowding into the same region and same industries may intensify competition and make it more costly for local prospective entrepreneurs to secure financial resources, hire workers, access network partners, share common infrastructure, and/or locate affordable land for their new firms (Folta et al. 2006). Because of these countering effects, theoretical predictions on the relationship between the scale of

\footnotetext{
${ }^{5}$ Because the performance of these two variables in our major 3SLS and system GMM regressions is insignificant, we exclude them in the major regressions.
} 
agglomeration and the activity level of new firm creation would be ambiguous. In the regression equations, we take natural logarithm of these two instrumental variables.

As we will see in Section 4, the 3SLS full system regression indicates that the system can be reduced to a recursive system and furthermore the 3SLS recursive system regression shows that the error terms of the two equations are not correlated: therefore, we can further apply the system GMM estimator as suggested by Arellano and Bover (1995) and Blundell and Bond (1998) to each of the two equations independently. The system GMM estimator also allows us to further control for the potential endogeneity of FDI density variables and other explanatory variables, and for unobserved region-specific effects and potential measurement errors. Under the System GMM, each equation is estimated by its first-order difference equation, which serves to remove the time-invariant fixed effects; and by the current level equation, which enables technical gains of additional moment conditions. Lagged first differences and lagged levels are used as instruments for the equation in levels and for the equation in first differences, respectively. Following the recommendations of Roodman (2009), we report the number of instrument variables used in the System GMM estimations with three sets of specification tests that assess whether a selected set of lagged-level and first-order differenced independent variables are valid instruments. First, Hansen's $J$ test of over-identifying restrictions is used to test for the overall validity of the instruments. Second, Difference-in-Hansen tests are conducted for the full set of instruments for the level equations. Third, first-order and second-order serial correlations in the first-differenced residuals are tested. If the original error terms are not serially correlated, evidence of a significant first-order serial correlation should appear, but no evidence 
Accepted version downloaded from SOAS Research Online: http://eprints.soas.ac.uk/22968/

of a second-order serial correlation in the first-order differenced residuals. In addition, a finite-

sample correction is made to the two-step covariance matrix as suggested in Windmeijer (2005).

\section{Empirical results}

\section{[Table 2 goes about here]}

Table 2 summarizes the descriptive statistics and a correlation matrix of the variables introduced in the previous section. ${ }^{6}$ According to the records of inward FDI notifications to Korea over the 5 years of 2000-2004 as reported in Lee \& Rugman (2009), the largest source region for total FDI to Korea was North America (36.2\%), followed by Europe (28.7\%) and Asia-Pacific (27.6\%). When the data coverage is narrowed down to manufacturing industries, the most important source region became Europe (34.5\%), followed by Asia-Pacific (31.7\%) and North America (20.5\%). In terms of inward FDI to Korea made by 2001 Fortune Global 500 companies over the same period, the dominant portion was made by European MNEs for both the overall investment $(55.5 \%)$ and investment in manufacturing industries $(52.8 \%)$. The above figures indicate that European and American MNEs were the major contributors of both capital investment and knowledge spillovers to the Korean economy.

\section{[Tables 3-5 go about here]}

\footnotetext{
${ }^{6}$ It is worth mentioning that for the least squares estimators, the correlations between location control variables have no impact on the unbiasedness of estimates although the correlations may affect the variances of the estimates (Greene 2008). In addition, the VIF statistics for the full set of explanatory variables is 8.97 for the high-tech equation and 8.95 for the low-tech equation, respectively, which are less than the popularly accepted critical value of 10. Therefore, multicollinearity in general or among locational control variables is not a serious problem in our empirical analysis.
} 
Table 3 reports the results of 3 SLS estimation of the full system. It first confirms the endogeneity of $\left(\right.$ NewFirm Low-Tech $_{i t}$ variable in the high-tech equation because its coefficient is positive and statistically significant at the $1 \%$ level. In contrast, the role of $\left(\right.$ NewFirm High-Tech $_{i t}$ in the low-tech equation is insignificant because its coefficient is indifferent from zero. These two results indicate that the full system can be reduced to a recursive system. We present the results of 3SLS estimation of the recursive system in Table 4.

Both Tables 3-4 show that in the high-tech equation, the coefficients of $\left(F D I_{\text {High-Tech }}\right)_{i, t-1}$ and $\left(\mathbf{W} \cdot F D I_{H i g h-T e c h}\right)_{i, t-1}$ are positive and statistically significant at the $1 \%$ level, ranging between 0.139 and 0.144 for the former and between 0.129 and 0.135 for the latter. Moreover, the coefficients of $\left(F D I_{H i g h-T e c h}^{2}\right)_{i, t-1}$ and $\left(\mathbf{W} \cdot F D I_{H i g h-T e c h}^{2}\right)_{i, t-1}$ are negative and significant at the $1 \%$ level, spanning between -0.015 and -0.014 for the former and between -0.022 and -0.020 for the latter. These results indicate that in the high-tech sector, there are significant FDI spillover effects from both the intra-regional and intra-sectoral channel and inter-regional and intra-sectoral channel, and furthermore, the effects follow an inverted ' $U$ '-shaped curvilinear pattern. However, all coefficients of inter-sectoral spillover variables are not significant. This contrast indicates that for new firm creation in the high-tech sector the statistically significant effects of FDI spillover come from the same sector within the same region and across the surrounding regions. On the other hand, it is also worth noting that although the effect of the intra-sectoral and intra-regional spillovers is numerically stronger than that of intra-sectoral and inter-regional one, the difference is not statistically significant.

With regard to the low-tech equation, all coefficients of sectoral and spatial variables in the recursive system estimation have the expected signs and are statistically significant. This 
Accepted version downloaded from SOAS Research Online: http://eprints.soas.ac.uk/22968/

suggests that the spillover effects of FDI in the low-tech sector are positive and significant and follow an inverted ' $U$ '-shaped pattern in each of the four possible channels of Figure 1.

Nevertheless, the results in the full system estimation are more conservative because the two coefficients of $\left(\mathbf{W} \cdot F D I_{H i g h-T e c h}\right)_{i, t-1}$ and $\left(\mathbf{W} \cdot F D I_{H i g h-T e c h}^{2}\right)_{i, t-1}$ become statistically insignificant. It is also interesting to note that in the full system estimation, the numerical strength-rank of the spillover effect in the low-tech sector is from the inter-sectoral and intra-regional effect (the strongest) to the intra-sectoral and intra-regional one (the second strongest), followed by intrasectoral and inter-regional, and the insignificant double inter-ones; furthermore the differences among the first three are not statistically significant.

Table 4 shows that the correlation coefficient between the error terms of the two recursive equations is very small (0.0193) and statistically insignificant $(p=0.5108)$. Therefore, it is justified to apply the system GMM estimator to each of the two equations independently and allow for endogeneity of the FDI density variables in the estimation. ${ }^{7}$ Table 5 reports the system GMM results. It can be seen from the table that the two regressions pass the specification tests of Hansen's $J$, Difference-in-Hansen, AR(1) and AR(2), which indicate that our selected set of instrument variables (IVs) is statistically valid, the potential endogeneity of inward FDI is appropriately addressed, and the two models are well-specified. Interestingly, the more

\footnotetext{
${ }^{7}$ There may be a potential endogeneity issue between new firm creation activities and inward FDI. Foreign firms may be attracted to certain geographic regions or industrial sectors because these regions or sectors offer the same degree and type of opportunities that attract local entrepreneurial firms such as a cluster of established firms, an abundance of cheap workforce, affordable land, etc. In addition, foreign capital injections may improve the economic performance of regions, thus further enhancing new opportunities for prospective entrepreneurs (Aitken and Harrison 1999). A lack of control for such potential endogeneity may generate biased and inconsistent empirical results.
} 
sophisticated system GMM estimator generates statistically equivalent results to those reported in Table 3, although the system GMM results are slightly more conservative in terms of the significance levels of the coefficients of the intra-sectoral spillover variables in the high-tech sector. This consistence shows the robustness of our results with respect to the alternative and valid estimation method.

In addition to the asymmetry of the estimation results of sectoral and spatial variables between the high-tech and low-tech equations, the results on location variables are also asymmetric. First, while the coefficients of both market size variables $\left(G R P P C_{i, t-1}\right.$ and $\left.P O P_{i, t-1}\right)$ are positive and significant in the low-tech equation as conventionally expected for more domestic and local market oriented low-tech industries (Keeble and Walker 1994), they are either insignificant or even have negative signs in the high-tech equation, which would be a reflection of the fact that high-tech industries in Korea basically have an international and interregional focus. Second, the coefficient on wage variable is negative and significant in the low-tech equation, which is in line with the labor cost constraint to the labor-intensive low-tech manufacturing (Audretsch and Vivarelli, 1996; Fritsch and Falck 2007), but it is positive and significant in the high-tech equation and this supports the argument that high-tech firms are in favor of locating in regions with high quality of human capital which is typically signaled by a high wage rate (Zucker et al., 1998). Third, the coefficient on land available for building factories is positive and significant in the low-tech equation, but negative and significant in the high-tech equation. This difference might be a reflection that new firms in low-tech sectors, which are typically more land-intensive, can be relatively easily located in suburban/rural areas of the host regions where the zoned industrial land are often available. In contrast, new firms in 
This is the accepted version of article first published online by Springer in Small Business Economics on 19 September 2016, available at: http://link.springer.com/article/10.1007/s11187-016-9803-0

Accepted version downloaded from SOAS Research Online: http://eprints.soas.ac.uk/22968/

high-tech sectors would like to reap agglomeration effects in the business centers of the host region for easy access to high-quality human capital and professional services (Jofre-Monseny et al 2014). A similar asymmetry holds for $T A X P C_{i, t-1}$ variable, which is consistent with our discussion in Section 3.3, and particularly with the argument that the negative effects of higher tax burden are strongest in industries characterized by higher relative profitability or value-added margin (Kneller and McGowan 2012; Papke 1991).

Following the convention in presenting 3SLS results, we report the results of the firststage estimation of the full system in Table A.1 of the appendix. ${ }^{8}$

\section{Discussion and conclusions}

Despite a substantial body of literature on the productivity-spillover of FDI, there has been limited research on the link between inward FDI and new firm creation in host countries. Among a few which investigate the spillover effects of FDI activities on firm founding activities by indigenous entrepreneurs, the focus has been on either sectoral or spatial spillovers. What remains absent is an integrated assessment of the joint sectoral and spatial effects owing to the modeling challenge posed by the complicated combinations of sectoral and spatial spillover channels. This study has aimed to meet this challenge and thus filling an important gap in the literature.

This study takes into consideration industrial and geographical linkages of FDI spillovers in addition to competition effects of FDI. First, industrial linkages of FDI spillovers are related to

\footnotetext{
${ }^{8}$ The robustness test based on a second-order contiguity spatial weight matrix produces statistically equivalent results and therefore we do not report them here.
} 
the labor market pooling, input sharing and knowledge spillovers between industries. Second, geographical linkages of FDI spillovers refer to localization theory of knowledge spillovers, which indicate that a successful commercialization process of new and entrepreneurial ideas possesses highly localized characteristics in geographic proximity. Third, competition effects of FDI indicate an entry barrier for indigenous entrepreneurs to launch new businesses due to increased market competition caused by the presence of FDI firms in the host market.

To integrate these three perspectives, this study specifies a simultaneous equations system with one equation for new firm creation in high-tech sector and the other for new firm creation in the low-tech sector. We employ 3SLS to estimate the full simultaneous equations system and employ both 3SLS and system GMM to estimate the two recursive equations. Because the error terms of the two recursive equations are not correlated, equation-by-equation system GMM estimation becomes applicable and it serves to further control for the potential endogeneity between new firm creation activities and inward FDI.

Using data on new ventures and inward FDI in high-tech and low-tech manufacturing sector in subnational regions of Korea, the empirical estimations show asymmetric results on FDI spillovers between the high- and low-tech sectors. The high-tech sector is more or less selfreinforcing because the impacts in the sector are largely intra-sectoral within the host region and across contiguous regions. In sharp contrast, for the low-tech sector, intra-regional FDI spillover from the high-tech sector is as important as the intra-sectoral ones. This contrast may at first seem counter-intuitive given the strong input-output linkage between the two sectors (JofreMonseny et al. 2011). Interestingly, it is the positive and significant presence of the density of low-tech new firms, i.e. $\left(\right.$ NewFirm Low-Tech $_{\text {it }}$ variable, in the high-tech equation that statistically 
represent and dominate the input-output relationship between the two sectors. As we expected, all statistically significant spillover effects follow an inverted ' $U$ '-shaped curvilinear trend.

The asymmetric results are also presented for location variables. While the results on the low-tech equation are consistent with conventions on labor-intensive low-tech industries, those on the high-tech equation are different. They suggest that high-tech industries in Korea have a highly international and interregional focus; high-tech firms in the country are in favor of locating in regions with high quality of human capital as signaled by a high wage rate (Zucker et al., 1998); high-tech firms are more keen to reap agglomeration effects in the business centers of the host region for easy access to high-quality human capital and professional services (JofreMonseny et al 2014); and the effects of higher tax burden are more burdensome for new firm creation in the high-tech sector than in the low-tech sector (Kneller and McGowan 2012; Papke 1991). These results are robust to two alternative and valid estimations. The first is the estimation of a reduced recursive equations system, and the second is the equation-by-equation estimations of the recursive system by the system General Method of Moment (GMM) estimator.

Two policy implications can be derived from this research. First, a systematic perspective in assessing the benefits and costs of location and agglomeration choices from all possible combinations of the intra-/inter-sectoral and intra-/inter-regional channels would help indigenous entrepreneurs to maximally reap the benefits of FDI spillovers and to minimize the costs of excessive competition at both the sectoral and regional level. The same perspective is also instructive to the managers of MNEs in their pursuits to foster collaborations with indigenous partners, to spur new firm creation activities in both upstream and downstream of the industrial value-chain, and to avoid strengthening the direct rivals. Second, policy measures intending to 
attract foreign investors and stimulate local entrepreneurial activities need to be designed not to surpass the threshold of the non-linear relationship between the presence of FDI operations and local entrepreneurial firm creation at the sectoral and regional level, because all statistically significant effects of FDI spillovers on domestic new firm creation follow an inverted 'U'shaped curvilinear trend and the shape of the curves is sector-specific.

In addition to the above insightful findings and their policy implications, this study further contributes to the regional science, entrepreneurship, and international business literature by integrating both the sectoral and spatial perspectives in modeling the effects of FDI spillovers on the activities of indigenous new firm creation and by developing a consistent and compact framework for such modeling and testing. This modeling framework and the associated empirical testing methods are clearly applicable to similar firm-level data from other countries. Future research in this direction would be able to check the extent to which the findings of this research can be generalized.

Two limitations of this study are worth mentioning. First, this study does not consider the heterogeneous country-of-origin effects of inward FDI projects, but it is well-acknowledged that FDI projects agglomerating with peers from countries in the proximity of the home country typically make stronger impacts on host country economies than agglomerating with those from remote countries (Rugman, 2005). Future research could examine this issue by dividing FDI projects into sub-groups based on country of origin. Second, the dichotomy of high-tech versus low-tech division might be too simple and it reduces the inter-sectoral spillover effects to a oneway traffic from the high-tech to the low-tech sector. Future research should work with more sectors than two. 
This is the accepted version of article first published online by Springer in Small Business Economics on 19 September 2016, available at: http://link.springer.com/article/10.1007/s11187-016-9803-0

Accepted version downloaded from SOAS Research Online: http://eprints.soas.ac.uk/22968/ 
This is the accepted version of article first published online by Springer in Small Business Economics on 19

September 2016, available at: http://link.springer.com/article/10.1007/s11187-016-9803-0

Accepted version downloaded from SOAS Research Online: http://eprints.soas.ac.uk/22968/

\section{References}

Acs, Z.J., Audretsch, D.B., \& Lehmann, E. (2013). The knowledge spillover theory of entreprenurship. Small Business Economcis, 41(4), 757-774. DOI: 10.1007/s11187-0139505-9

Aitken, B.J., \& Harrison, A.E. (1999). Do domestic firms benefit from foreign direct investment? Evidence from Venezuela. American Economic Review, 89(3), 605-618. DOI: 10.1257/aer.89.3.605

Altomonte, C., \& Pennings, E. (2009). Domestic plant productivity and incremental spillovers from foreign direct investment. Journal of International Business Studies, 40(7), 1131-1148. DOI:10.1057/jibs.2008.99

Arellano, M., \& Bover, O. (1995). Another look at instrumental variable estimation of errorcomponent models. Journal of Econometrics, 68(1), 29-52. DOI:10.1016/03044076(94)01642-D

Athukorala, P.-C. (2003). FDI in Crisis and Recovery: Lessons from the 1997-1998 Asian Crisis. Australian Economic History Review, 43(2), 197-213. DOI: 10.1111/1467-8446.t01-1-00051

Audretsch, D.B., \& Feldman, M.P. (2004). Knowledge spillovers and the geography of innovation. In V. Henderson, \& J.-F. Thisse (Eds.), Handbook of Regional and Urban Economics: Cities and Geography. Oxford: North Holland and Elsevier, Vol. 4, pp. 27132739.

Audretsch, D.B., \& Keilbach, M. (2007). The theory of knowledge spillover entrepreneurship. Journal of Management Studies, 44(7), 1242-1254. DOI: 10.1111/j.1467-6486.2007.00722.x 
This is the accepted version of article first published online by Springer in Small Business Economics on 19

September 2016, available at: http://link.springer.com/article/10.1007/s11187-016-9803-0

Accepted version downloaded from SOAS Research Online: http://eprints.soas.ac.uk/22968/

Audretsch, D.B., \& Lehmann, E.E. (2005). Does the knowledge spillover theory of entrepreneurship hold for regions? Research Policy, 34(8), 1191-1202.

DOI:10.1016/j.respol.2005.03.012

Audretsch, D.B., Lehmann, E.E., \& Warning, S. (2005). University spillovers and new firm location. Research Policy, 34(7), 1113-1122. DOI:10.1016/j.respol.2005.05.009

Audretsch, D. B. and Vivarelli, M. (1996), Determinants of New-Firm Startups in Italy, Empirica, 23: 91-105. DOI: 10.1007/BF00925009

Ayyagari, M., \& Kosová, R. (2010). Does FDI facilitate domestic entry? Evidence from the Czech Republic. Review of International Economics, 18(1), 14-29. DOI: 10.1111/j.14679396.2009.00854.x

Barbosa, N., \& Eiriz, V. (2009). The role of inward foreign direct investment on entrepreneurship. International Entrepreneurship and Management Journal, 5(3), 319-339. DOI: $10.1007 / \mathrm{s} 11365-007-0050-3$

Barrios, S., Görg, H., \& Strobl, F. (2005). Foreign direct investment, competition and industrial development in the host country. European Economic Review, 49(7), 1761-1784. DOI: doi:10.1016/j.euroecorev.2004.05.005

Berry, M.M.J., \& Taggart, J.H. (1998). Combining technology and corporate strategy in small high tech firms. Research Policy, 26(7-8), 883-895. DOI:10.1016/S0048-7333(97)00064-4

Bhat, C.R., Paleti, R. \& Singh, P. (2014). A spacial multivariate count model for firm location decisions. Journal of Regional Science, 54(3), 462-502. DOI: 10.1111/jors.12101 
This is the accepted version of article first published online by Springer in Small Business Economics on 19

September 2016, available at: http://link.springer.com/article/10.1007/s11187-016-9803-0

Accepted version downloaded from SOAS Research Online: http://eprints.soas.ac.uk/22968/

Blalock, G., \& Gertler, P.J. (2008). Welfare gains from foreign direct investment through technology transfer to local suppliers. Journal of International Economics, 74(2), 402-421. DOI:10.1016/j.jinteco.2007.05.011

Blau, P.M. (1977). Inequality and heterogeneity. New York: Free Press.

Blundell, R., \& Bond, S.R. (1998). Initial conditions and moment restrictions in dynamic panel data models. Journal of Econometrics, 87(1), 115-143. DOI:10.1016/S0304-4076(98)000098

Brush, C.G., \& Vanderwerf, P.A. (1992). A comparison of methods and sources for obtaining estimates of new venture performance. Journal of Business Venturing, 7(2), 157-170. DOI:10.1016/0883-9026(92)90010-O

Burke, A., Görg, H., \& Hanley, A. (2008). The impact of foreign direct investment on new firm survival in the UK: evidence for static versus dynamic industries. Small Business Economcis, 31(4) , 395-407. DOI: 10.1007/s11187-007-9065-y

Buckley, P.J., Clegg, J., \& Wang, C. (2006). Inward FDI and host country productivity: Evidence from China's electronics industry. Transnational Corporations, 15(1), 13-37. http://unctad.org/en/Docs/iteiit20061_en.pdf

Buckley, P.J., Clegg, J., \& Wang, C. (2007). Is the relationship between inward FDI and spillover effects linear? An empirical examination of the case of China. Journal of International Business Studies, 38(3), 447-459. DOI:10.1057/palgrave.jibs.8400274

Caves, R.E. (1974). Multinational firms, competition and productivity in host country markets. Economica, 41, 176-193. DOI: 10.2307/2553765 
This is the accepted version of article first published online by Springer in Small Business Economics on 19

September 2016, available at: http://link.springer.com/article/10.1007/s11187-016-9803-0

Accepted version downloaded from SOAS Research Online: http://eprints.soas.ac.uk/22968/

Caves, R.E. (1996). Multinational Enterprise and Economic Analysis. New York: Cambridge University Press.

Clark, D.P., \& Highfill, J. (2011). FDI, technology spillovers, growth, and income inequality: A selective survey. Global Economy Journal, 11(2), 1-42. DOI: 10.2202/1524-5861.1773

Cohen, W.M., \& Levinthal, D.A. (1990). Absorptive capacity: A new perspective on learning and innovation. Administrative Science Quarterly, 35(1), 128-152. DOI: $10.2307 / 2393553$

Cooper, A.C., \& Folta, T. (2000). Entrepreneurship and high-technology clusters. In D. L.

Sexton and H. Lanstrom (Eds.), The Blackwell Handbook of Entrepreneurship (pp. 348-367). Oxford: Blackwell.

Covin, J.G., Slevin, D.P., \& Covin, T.J. (1990). Content and performance of growth-seeking strategies: A comparison of small firms in high- and low-technology industries. Journal of Business Venturing, 5(6), 391-412. DOI:10.1016/0883-9026(90)90013-J

De Backer, K., \& Sleuwaegen, L. (2003). Does foreign direct investment crowd out domestic entrepreneurship? Review of Industrial Organization, 22(1), 97-84. DOI: 10.1023/A:1022180317898

Folta, T.B., Cooper, A.C., \& Baik, Y. (2006). Geographic cluster size and firm performance. Journal of Business Venturing, 21(2), 217-242. DOI:10.1016/j.jbusvent.2005.04.005

Fritsch, M., \& Falck, O. (2007). New business formation by industry over space and time: A multidimensional analysis. Regional Studies, 41(2), 157-172.

DOI:10.1080/00343400600928301 
This is the accepted version of article first published online by Springer in Small Business Economics on 19

September 2016, available at: http://link.springer.com/article/10.1007/s11187-016-9803-0

Accepted version downloaded from SOAS Research Online: http://eprints.soas.ac.uk/22968/

Garcia, F., Jin, B., \& Salomon, R. (2013). Does inward foreign direct investment improve the innovative performance of local firms? Research Policy, 42(1), 231-244.

DOI:10.1016/j.respol.2012.06.005

Gilbert, B.A., McDougall, P.P., \& Audretsch, D.B. (2008). Clusters, knowledge spillovers and new venture performance: An empirical examination. Journal of Business Venturing, 23(4), 405-422. DOI:10.1016/j.jbusvent.2007.04.003

Görg, H., \& Strobl, E. (2002). Multinational companies and indigenous development: An empirical analysis. European Economic Review, 46(7), 1305-1322. DOI:10.1016/S00142921(01)00146-5

Greene, W.H. (2008). Econometric Analysis. 6th ed., New Jersey: Pearson Education Inc.

Haddad, M., \& Harrison, A.E. (1993). Are there positive spillovers from direct foreign investment? Journal of Development Economics, 42(1), 51-74. DOI:10.1016/03043878(93)90072-U

Haskel, J.E., Pereira, S.C., \& Slaughter, M.J. (2007). Does inward foreign direct investment boost the productivity of domestic firms? The Review of Economics and Statistics, 89(3), 482-496. DOI:10.1162/rest.89.3.482

Helmers, C., \& Rogers, M. (2011). Does patenting help high-tech start-ups? Research Policy, 40(7), 1016-1027. DOI:10.1016/j.respol.2011.05.003

Javorcik, B.S. (2004). Does foreign direct investment increase the productivity of domestic firms? In search of spillovers through backward linkages American Economic Review, 94(3), 605-627. DOI: $10.1257 / 0002828041464605$ 
This is the accepted version of article first published online by Springer in Small Business Economics on 19

September 2016, available at: http://link.springer.com/article/10.1007/s11187-016-9803-0

Accepted version downloaded from SOAS Research Online: http://eprints.soas.ac.uk/22968/

Jofre-Monseny, J., Marín-López, R., \& Viladecans-Marsal, E. (2011). The mechanisms of agglomeration: Evidence from the effect of inter-industry relations on the location of new firms Journal of Urban Economics, 70(2-3), 61-74. DOI:10.1016/j.jue.2011.05.002

Jofre-Monseny, J., Marín-López, R., \& Viladecans-Marsal, E. (2014). The determinants of localization and urbanization economies: Evidence from the location of new firms in Spain. Journal of Regional Science, 54(2), 313-337. DOI: 10.1111/jors.12076

Keeble, D., \& Walker, S. (1994). New firms, small firms and dead firms: Spatial patterns and determinants in the United Kingdom. Regional Studies, 28(4), 411-427. DOI: $10.1080 / 00343409412331348366$

Kim, J.-D. \& Hwang, S.-I. (2000). The role of foreign direct investment in Korea's economic development: Productivity effects and implications for the currency crisis. In Krueger, A.O. \& Ito, T. (Eds.), The role of foreign direct investment in East Asian economic development (pp. 267-94). Chicago: University of Chicago Press.

Kirner, E., Kinkel, S., \& Jaeger, A. (2009) Innovation paths and the innovation performance of low-technology firms - An empirical analysis of German industry. Research Policy, 38(3), 447-458. DOI:10.1016/j.respol.2008.10.011

Kneller, R., \& McGowan, D. (2012). Tax policy and firm entry and exit dynamics: Evidence from OECD countries. Bangor Business School Working Paper BBSWP/12/006, Bangor University, UK.

Korea, Ministry of Commerce, Industry and Energy. (2003) Performance of the Attraction of Inward FDI for the Past 5 Years: Special Report to the Minister. Seoul, Korea: MOCIE. 
This is the accepted version of article first published online by Springer in Small Business Economics on 19

September 2016, available at: http://link.springer.com/article/10.1007/s11187-016-9803-0

Accepted version downloaded from SOAS Research Online: http://eprints.soas.ac.uk/22968/

Lee, I. H., Hong, E, \& Sun, L. (2014). Inward foreign direct investment and domestic entrepreneurship: A regional analysis of new firm creation in Korea. Regional Studies, 48(5): 910-922. DOI:10.1080/00343404.2012.690067

Lee, I.H. and Rugman, A.M. (2009) Multinationals and Public Policy in Korea. Asian Business \& Management, 8(1): 59-82. DOI:10.1057/abm.2008.24

Linder, S. (1961). An Essay on Trade and Transformation. Uppsala: Almqvist and Wiksells. Marshall, A. 1890. Principle of Economics. London: Macmillan.

McPherson, J.M., \& Smith-Lovin, L. (1987). Homophily in voluntary organizations: Status distance and the composition of face to face groups. American Sociological Review, 52(3), 370-379. http://www.jstor.org/stable/2095356

Motohashi, K., \& Yuan, Y. (2010). Productivity impact of technology spillover from multinationals to local firms: Comparing China's automobile and electronics industries. Research Policy, 39(6), 790-798. DOI:10.1016/j.respol.2010.02.014

Murphy, K.M., Shleifer, A., \& Vishny, R.W. (1989). Income Distribution, Market Size, and Industrialization. Quarterly Journal of Economics, 104(3), 537-564. DOI: 10.2307/2937810

Nicolas, F. (2003). FDI as a Factor of Economic Restructuring: The Case of South Korea. In Bende-Nabende, A. (Eds.), International Trade, Capital Flows and Economic Development in East Asia - The Challenge in the 21st century. Ashgate, Aldershot.

Nunes, P.M., Serrasqueiro, Z., \& Leitão, J. (2012). Is there a linear relationship between R\&D intensity and growth? Empirical evidence of non-high-tech vs. high-tech SMEs. Research Policy, 41(1), 36-53. DOI:10.1016/j.respol.2011.08.011 
This is the accepted version of article first published online by Springer in Small Business Economics on 19

September 2016, available at: http://link.springer.com/article/10.1007/s11187-016-9803-0

Accepted version downloaded from SOAS Research Online: http://eprints.soas.ac.uk/22968/

OECD. (2000). Policy competition for foreign direct investment: A study of competition among governments to attract FDI. Paris, France: Development Centre of the Organisation for Economic Cooperation and Development.

Papke, L.E. (1991). Interstate business tax differentials and new firm location: Evidence from panel data. Journal of Public Economics, 45(1), 47-68. DOI:10.1016/0047-2727(91)90047-6

Pfeffer, J., \& Salancik, G.R. (1978). The External Control of Organizations: A resource dependence perspective. New York: Harper \& Row.

Ramezzana, P. (2000). Per capita income, demand for variety, and international trade: Linder reconsidered. Centre for Economic Performance Discussion Paper DP0460, London School of Economics and Political Science, UK.

Roodman, D. (2009). A note on the theme of too many instruments. Oxford Bulletin of Economics and Statistics, 71(1), 135-158. DOI: 10.1111/j.1468-0084.2008.00542.x

Rothaermel, F.T., \& Thursby, M. (2005). University-incubator firm knowledge flows: Assessing their impact on incubator firm performance. Research Policy, 34(3), 305-320.

DOI:10.1016/j.respol.2004.11.006

Rugman, A.M. (2005). The regional multinationals. Cambridge: Cambridge University Press.

Sorenson, O., \& Stuart, T.E. (2001). Syndication networks and the spatial distribution of venture capital investments. The American Journal of Sociology, 106(6), 1546-1588. DOI:

$10.1086 / 321301$

Stuart, T., \& Sorenson, O. (2003). The geography of opportunity: spatial heterogeneity in founding rates and the performance of biotechnology firms. Research Policy, 32(2), 229253. DOI:10.1016/S0048-7333(02)00098-7 
This is the accepted version of article first published online by Springer in Small Business Economics on 19

September 2016, available at: http://link.springer.com/article/10.1007/s11187-016-9803-0

Accepted version downloaded from SOAS Research Online: http://eprints.soas.ac.uk/22968/

Sutaria, V., \& Hicks, D.A. (2004). New firm formation: Dynamics and determinants. Annals of Regional Science, 38(2), 241-262. DOI: 10.1007/s00168-004-0194-9

Thornhill, S. (2006). Knowledge, innovation and firm performance in high- and low-technology regimes. Journal of Business Venturing, 21(5), 687-703.

DOI:10.1016/j.jbusvent.2005.06.001

UNCTAD. (2013). World Investment Report. New York: United Nations.

Von Hipple, E. (1994). Sticky information and the locus of problem solving: Implications for innovation. Management Science, 40(4), 429-439. http://dx.doi.org/10.1287/mnsc.40.4.429

Windmeijer, F. (2005). A finite sample correction for the variance of linear efficient two-step GMM estimators. Journal of Econometrics, 126(1), 25-51.

DOI:10.1016/j.jeconom.2004.02.005

Woodward, D.P. (1992). Locational determinants of Japanese manufacturing start-ups in the United Sates. Southern Economic Journal, 58(3), 690-708. DOI: 10.2307/1059836

Zahra, S., Ireland, D., \& Hitt, M. (2000). International expansion by new venture firms: International diversity, mode of market entry, technological learning, and performance. Academy of Management Journal, 43(5), 925-950. DOI: 10.2307/1556420

Zaheer, S. (1995). Overcoming the liability of foreignness. Academy of Management Journal, 38(2), 341-363. DOI: $10.2307 / 256683$

Zucker, L.G., Darby, M.R., \& Brewer, M.B. (1998). Intellectual human capital and the birth of U.S. biotechnology enterprises. American Economic Review, 88(1), 290-306. http://www.jstor.org/stable/116831 
This is the accepted version of article first published online by Springer in Small Business Economics on 19 September 2016, available at: http://link.springer.com/article/10.1007/s11187-016-9803-0

\section{Accepted version downloaded from SOAS Research Online: http://eprints.soas.ac.uk/22968/}

Figure 1. The Channels of FDI Spillovers

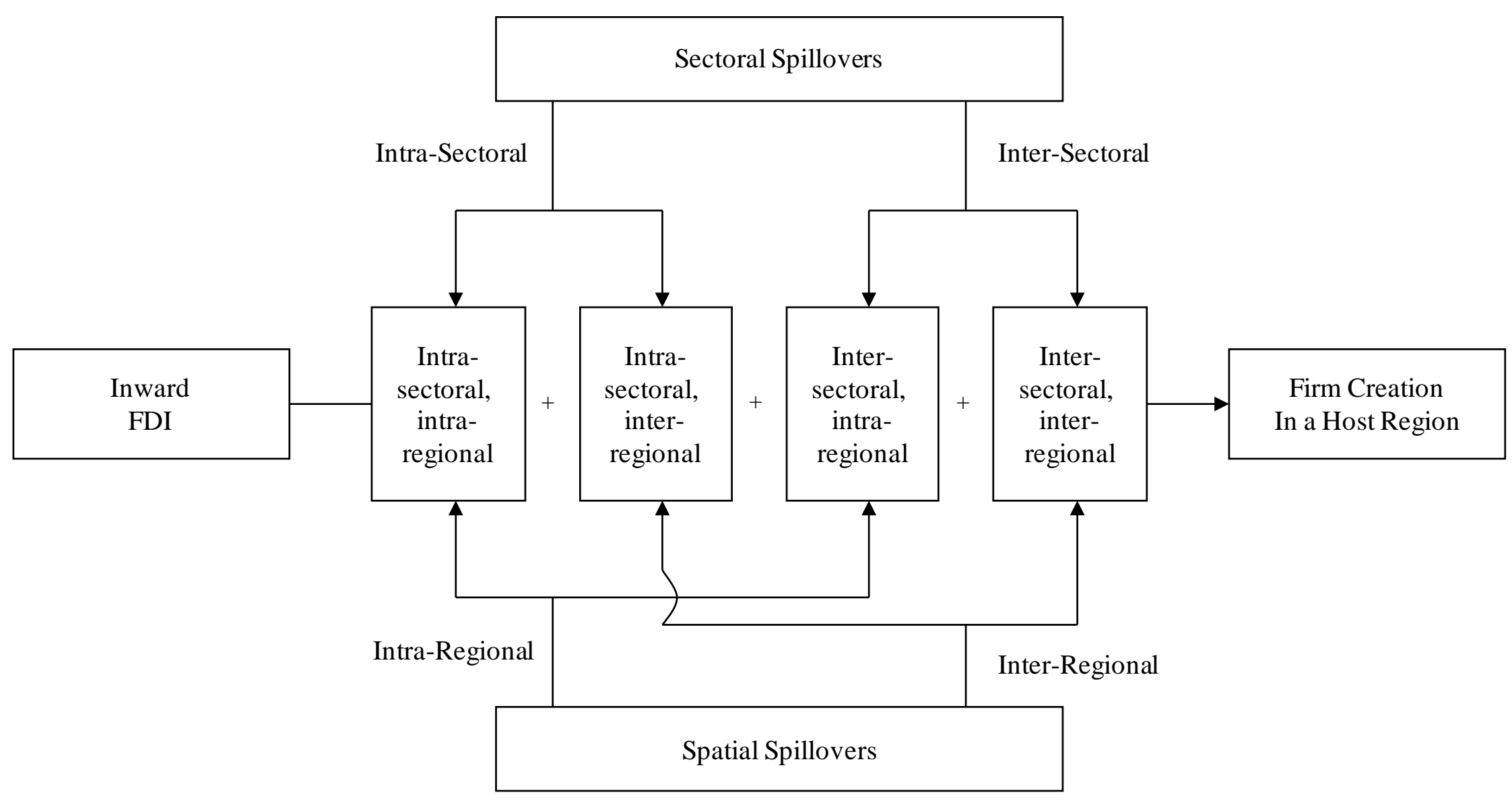


Table 1. Coefficients and their expected signs

\begin{tabular}{|l|l|l|}
\hline Coefficients & Expected Signs & Theoretical Arguments \\
\hline$\beta_{1}^{1}$ and $\beta_{1}^{2}$ & Positive & Input-Output connections \\
\hline$\beta_{2}^{1}, \beta_{2}^{2}, \beta_{4}^{1}, \beta_{4}^{2}, \beta_{6}^{1}, \beta_{6}^{2}, \beta_{8}^{1}$, and $\beta_{8}^{2}$ & Positive & Sectoral \& spatial spillovers \\
\hline$\beta_{3}^{1}, \beta_{3}^{2}, \beta_{5}^{1}, \beta_{5}^{2}, \beta_{7}^{1}, \beta_{7}^{2}, \beta_{9}^{1}$, and $\beta_{9}^{2}$ & Negative & Sectoral \& spatial competition \\
\hline$\beta_{10}^{1}$ and $\beta_{10}^{2}$ & Positive/Negative & $\begin{array}{l}\text { Trade-off between richness and } \\
\text { population size in terms of market size }\end{array}$ \\
\hline$\beta_{11}^{1}$ and $\beta_{11}^{2}$ & Positive/Negative & Labor expenses versus quality \\
\hline$\beta_{12}^{1}$ and $\beta_{12}^{2}$ & Positive & Urban development zoning policy \\
\hline$\beta_{13}^{1}$ & Positive/Negative & $\begin{array}{l}\text { Better public services versus increasing } \\
\text { tax burdens }\end{array}$ \\
\hline$\beta_{13}^{2}$ & Positive/Negative & $\begin{array}{l}\text { Trade-off between richness and } \\
\text { population size in terms of market size }\end{array}$ \\
\hline
\end{tabular}


Table 2. Descriptive statistics and correlation matrix ${ }^{a, b}$

\begin{tabular}{|c|c|c|c|c|c|c|c|c|c|c|c|c|c|c|}
\hline & & Mean & S. D. & 1 & 2 & 3 & 4 & 5 & 6 & 7 & 8 & 9 & 10 & 11 \\
\hline 1 & $\left(\text { NewFirm }_{\text {High-Tech }}\right)_{i t}$ & 0.09 & 0.18 & 1.00 & & & & & & & & & & \\
\hline 2 & $\left(\text { NewFirm }_{\text {Low-Tech }}\right)_{i t}$ & 0.34 & 0.55 & $0.81 * * *$ & 1.00 & & & & & & & & & \\
\hline 3 & $\left(F D I_{H i g h-T e c h}\right)_{i, t-1}$ & 0.16 & 0.57 & $0.38^{* * *}$ & $0.21 * * *$ & 1.00 & & & & & & & & \\
\hline 4 & $\left(F D I_{\text {Low-Tech }}\right)_{i, t-1}$ & 0.27 & 0.70 & $0.31 * * *$ & $0.28 * * *$ & $0.68^{* * *}$ & 1.00 & & & & & & & \\
\hline 5 & $\left(\mathbf{W} \cdot F D I_{H i g h-T e c h}\right)_{i, t-1}$ & 0.18 & 0.36 & $0.34 * * *$ & $0.17 * * *$ & $0.48^{* * *}$ & $0.33^{* * *}$ & 1.00 & & & & & & \\
\hline 6 & $\left(\mathbf{W} \cdot F D I_{L o w-T e c h}\right)_{i, t-1}$ & 0.29 & 0.39 & $0.32 * * *$ & $0.20 * * *$ & $0.36^{* * * *}$ & $0.35^{* * *}$ & $0.74 * * *$ & 1.00 & & & & & \\
\hline 7 & $\ln G R P P C_{i, t-1}$ & 1.43 & 1.48 & $0.39^{* * *}$ & $0.47^{* * *}$ & $0.13^{* * *}$ & $0.21 * * *$ & $0.06^{*}$ & $0.05^{*}$ & 1.00 & & & & \\
\hline 8 & $\ln$ Wage $_{i, t-1}$ & 0.22 & 0.32 & $0.24 * * *$ & $0.21 * * *$ & $0.17^{* * *}$ & $0.18^{* * * *}$ & $0.21 * * *$ & $0.16^{* * * *}$ & $0.67 * * *$ & 1.00 & & & \\
\hline 9 & $\ln$ LandSize $_{i, t-1}$ & 0.25 & 1.23 & -0.01 & $0.14 * * *$ & $-0.15^{* * *}$ & $-0.16 * * *$ & $-0.36^{* * *}$ & $-0.41 * * *$ & $0.30 * * *$ & $0.07 * *$ & 1.00 & & \\
\hline 10 & $\ln T A X P C_{i, t-1}$ & -0.86 & 0.57 & $0.21^{* * *}$ & $0.20 * * *$ & $0.34 * * *$ & $0.33^{* * * *}$ & $0.41^{* * *}$ & $0.31 * * *$ & 0.24 & $0.41 * * *$ & $-0.20 * * *$ & 1.00 & \\
\hline 11 & $\ln P O P_{i, t-1}$ & 11.84 & 0.94 & $0.43^{* * *}$ & $0.39 * * *$ & $0.32 * * *$ & $0.33^{* * *}$ & $0.37^{* * *}$ & $0.43 * * *$ & $0.14 * * *$ & $0.28 * * *$ & $-0.30^{* * *}$ & $0.26 * * *$ & 1.00 \\
\hline
\end{tabular}

Notes. a. $\mathrm{N}=1,166$. b. Significance levels: $* p<0.10, * * p<0.05, * * * p<0.01$. 
Table 3. The results of 3SLS estimation of the full system

\begin{tabular}{|c|c|c|}
\hline & $\left(\text { NewFirm }_{\text {High-Tech }}\right)_{i t}$ & $\left(\text { NewFirm } m_{\text {Low-Tech }}\right)_{i t}$ \\
\hline \multicolumn{3}{|l|}{ Endogenous Variables } \\
\hline$\left(\text { NewFirm }_{\text {High-Tech }}\right)_{i t}$ & & $-1.212[1.340]$ \\
\hline$\left(\text { NewFirm }_{\text {Low-Tech }}\right)_{i t}$ & $0.263^{* * *}[0.024]$ & \\
\hline \multicolumn{3}{|l|}{$\begin{array}{l}\text { Sectoral \& Spatial } \\
\text { FDI Spillover Variables }\end{array}$} \\
\hline$\left(F D I_{H i g h-T e c h}\right)_{i, t-1}$ & $0.139 * * *[0.013]$ & $0.447 *[0.265]$ \\
\hline$\left(F D I_{H i g h-T e c h}^{2}\right)_{i, t-1}$ & $-0.014 * * *[0.002]$ & $-0.072 * *[0.035]$ \\
\hline$\left(F D I_{\text {Low-Tech }}\right)_{i, t-1}$ & $-0.014[0.012]$ & $0.329 * * *[0.082]$ \\
\hline$\left(F D I_{\text {Low-Tech }}^{2}\right)_{i, t-1}$ & $-0.001[0.002]$ & $-0.044 * * *[0.015]$ \\
\hline$\left(\mathbf{W} \cdot F D I_{H i g h-T e c h}\right)_{i, t-1}$ & $0.135^{* * *}[0.021]$ & $0.393[0.258]$ \\
\hline$\left(\mathbf{W} \cdot F D I_{H i g h-T e c h}^{2}\right)_{i, t-1}$ & $-0.020 * * *[0.005]$ & $-0.069[0.047]$ \\
\hline$\left(\mathbf{W} \cdot F D I_{\text {Low-Tech }}\right)_{i, t-1}$ & $-0.020[0.019]$ & $0.252 * *[0.105]$ \\
\hline$\left(\mathbf{W} \cdot F D I_{L o w-T e c h}^{2}\right)_{i, t-1}$ & $0.001[0.003]$ & $-0.053 * * *[0.019]$ \\
\hline \multicolumn{3}{|l|}{ Location Variables } \\
\hline $\ln G R P P C_{i, t-1}$ & $-0.003[0.004]$ & $0.201 * * *[0.053]$ \\
\hline $\ln$ Wage $_{i, t-1}$ & $0.034 * *[0.017]$ & $-0.680 * * *[0.177]$ \\
\hline $\ln$ LandSize $_{i, t-1}$ & $-0.009 * * *[0.003]$ & $0.077 * * *[0.020]$ \\
\hline $\ln T A X P C_{i, t-1}$ & $-0.035 * * *[0.006]$ & \\
\hline $\ln P O P_{i, t-1}$ & & $0.199 * * *[0.057]$ \\
\hline Constant & $-0.059 * * *[0.011]$ & $-2.400 * * *[0.703]$ \\
\hline Industrial Complex Dummies & Yes & Yes \\
\hline Year Dummies & Yes & Yes \\
\hline$F$-Statistics & $108.48^{* * *}$ & $32.02 * * *$ \\
\hline $\mathrm{R}^{2}$ & 0.749 & 0.112 \\
\hline
\end{tabular}

Notes. a. $\mathrm{N}=1,166$. b. Significance levels: $* p<0.10$, $* * p<0.05$, $* * * p<0.01$. c. Numbers in [ ] are standard errors. 
Table 4. The results of 3SLS estimation of the recursive system

\begin{tabular}{|c|c|c|}
\hline & $\left(\text { NewFirm }_{\text {High-Tech }}\right)_{i t}$ & $\left(\text { NewFirm }{ }_{\text {Low-Tech }}\right)_{i t}$ \\
\hline \multicolumn{3}{|l|}{ Endogenous Variables } \\
\hline \multicolumn{3}{|l|}{$\left(\text { NewFirm }_{\text {High-Tech }}\right)_{i t}$} \\
\hline$\left(\text { NewFirm }_{\text {Low-Tech }}\right)_{i t}$ & $0.237 * * *[0.024]$ & \\
\hline \multicolumn{3}{|l|}{$\begin{array}{l}\text { Sectoral \& Spatial } \\
\text { FDI Spillover Variables }\end{array}$} \\
\hline$\left(F D I_{H i g h-T e c h}\right)_{i, t-1}$ & $0.144 * * *[0.013]$ & $0.209 * * *[0.048]$ \\
\hline$\left(F D I_{H i g h-T e c h}^{2}\right)_{i, t-1}$ & $-0.015 * * *[0.002]$ & $-0.042 * * *[0.009]$ \\
\hline$\left(F D I_{\text {Low-Tech }}\right)_{i, t-1}$ & $-0.013[0.012]$ & $0.258 * * *[0.038]$ \\
\hline$\left(F D I_{\text {Low-Tech }}^{2}\right)_{i, t-1}$ & $-0.002[0.002]$ & $-0.032 * * *[0.005]$ \\
\hline$\left(\mathbf{W} \cdot F D I_{H i g h-T e c h}\right)_{i, t-1}$ & $0.129 * * *[0.022]$ & $0.166^{*}[0.089]$ \\
\hline$\left(\mathbf{W} \cdot F D I_{H i g h-T e c h}^{2}\right)_{i, t-1}$ & $-0.022 * * *[0.005]$ & $-0.034 *[0.019]$ \\
\hline$\left(\mathbf{W} \cdot F D I_{L o w-T e c h}\right)_{i, t-1}$ & $-0.014[0.019]$ & $0.208 * * *[0.073]$ \\
\hline$\left(\mathbf{W} \cdot F D I_{\text {Low-Tech }}^{2}\right)_{i, t-1}$ & $0.001[0.003]$ & $-0.041 * * *[0.012]$ \\
\hline \multicolumn{3}{|l|}{ Location Variables } \\
\hline $\ln G R P P C_{i, t-1}$ & $0.001[0.004]$ & $0.155^{* * *}[0.012]$ \\
\hline $\ln$ Wage $_{i, t-1}$ & $0.009 * *[0.016]$ & $-0.558 * * *[0.056]$ \\
\hline $\ln$ LandSize $_{i, t-1}$ & $-0.007 * *[0.003]$ & $0.069 * * *[0.012]$ \\
\hline $\ln T A X P C_{i, t-1}$ & & $0.057 * *[0.025]$ \\
\hline $\ln P O P_{i, t-1}$ & & $0.151 * * *[0.016]$ \\
\hline Constant & $-0.017 * *[0.008]$ & $-1.737 * * *[0.186]$ \\
\hline Industrial Complex Dummies & Yes & Yes \\
\hline Year Dummies & Yes & Yes \\
\hline$F$-Statistics & $110.23 * * *$ & $54.23 * * *$ \\
\hline $\mathrm{R}^{2}$ & 0.744 & 0.494 \\
\hline $\begin{array}{l}\text { Correlation between the error } \\
\text { terms of the two equations }\end{array}$ & \multicolumn{2}{|c|}{$r=0.0193(p=0.5108)$} \\
\hline
\end{tabular}

Notes. The same as in Table 3. 
Table 5. The results of System GMM estimation

\begin{tabular}{|c|c|c|}
\hline & $\left(\text { NewFirm }_{\text {High-Tech }}\right)_{i t}$ & $\left(\text { NewFirm }{ }_{\text {Low-Tech }}\right)_{i t}$ \\
\hline \multicolumn{3}{|l|}{ Endogenous Variables } \\
\hline \multicolumn{3}{|l|}{$\left(\text { NewFirm }_{\text {High-Tech }}\right)_{i t}$} \\
\hline$\left(\text { NewFirm }_{\text {Low-Tech }}\right)_{i t}$ & $0.343 * * *[0.043]$ & \\
\hline \multicolumn{3}{|l|}{$\begin{array}{l}\text { Sectoral \& Spatial } \\
\text { FDI Spillover Variables }\end{array}$} \\
\hline$\left(F D I_{H i g h-T e c h}\right)_{i, t-1}$ & $0.105 * *[0.031]$ & $0.245^{* * *}[0.079]$ \\
\hline$\left(F D I_{H i g h-T e c h}^{2}\right)_{i, t-1}$ & $-0.008 *[0.005]$ & $-0.035 * * *[0.010]$ \\
\hline$\left(F D I_{\text {Low-Tech }}\right)_{i, t-1}$ & $-0.044[0.030]$ & $0.114 *[0.063]$ \\
\hline$\left(F D I_{\text {Low-Tech }}^{2}\right)_{i, t-1}$ & $0.002[0.003]$ & $-0.021 * * *[0.007]$ \\
\hline$\left(\mathbf{W} \cdot F D I_{H i g h-T e c h}\right)_{i, t-1}$ & $0.098 *[0.058]$ & $0.162[0.126]$ \\
\hline$\left(\mathbf{W} \cdot F D I_{H i g h-T e c h}^{2}\right)_{i, t-1}$ & $-0.015[0.010]$ & $-0.034[0.025]$ \\
\hline$\left(\mathbf{W} \cdot F D I_{\text {Low-Tech }}\right)_{i, t-1}$ & $-0.039[0.025]$ & $0.113 *[0.059]$ \\
\hline$\left(\mathbf{W} \cdot F D I_{L o w-T e c h}^{2}\right)_{i, t-1}$ & $0.003[0.004]$ & $-0.025 * *[0.011]$ \\
\hline \multicolumn{3}{|l|}{ Location Variables } \\
\hline $\ln G R P P C_{i, t-1}$ & $-0.013 * *[0.006]$ & $0.112 * * *[0.025]$ \\
\hline $\ln$ Wage $_{i, t-1}$ & $0.027 *[0.018]$ & $-0.318^{* * *}[0.119]$ \\
\hline $\ln$ LandSize $_{i, t-1}$ & $-0.004[0.005]$ & $0.045 * *[0.019]$ \\
\hline $\ln T A X P C_{i, t-1}$ & & $0.070[0.047]$ \\
\hline $\ln P O P_{i, t-1}$ & & $0.123 * * *[0.027]$ \\
\hline Constant & $-0.008[0.005]$ & $-1.321 * * *[0.314]$ \\
\hline Industrial Complex Dummies & Yes & Yes \\
\hline Year Dummies & Yes & Yes \\
\hline$F$-Statistics & $10.63 * * *$ & $7.21 * * *$ \\
\hline Number of Instruments & 85 & 89 \\
\hline Hansen's $J$ Test & $(0.226)$ & $(0.730)$ \\
\hline Difference-in-Hansen Test & $(0.159)$ & $(0.667)$ \\
\hline $\operatorname{AR}(1)$ & $(0.000)$ & $(0.001)$ \\
\hline $\operatorname{AR}(2)$ & $(0.239)$ & $(0.832)$ \\
\hline
\end{tabular}

Notes. The same as in table 3 and numbers in ( ) are $p$-values. 
Table A.1. The results of the first-stage estimation of the full system

\begin{tabular}{|c|c|c|}
\hline & $\left(\text { NewFirm }_{\text {High-Tech }}\right)_{i t}$ & $\left(\text { NewFirm }_{\text {Low-Tech }}\right)_{i t}$ \\
\hline \multicolumn{3}{|l|}{$\begin{array}{l}\text { Sectoral \& Spatial } \\
\text { FDI Spillover Variables }\end{array}$} \\
\hline$\left(F D I_{\text {High-Tech }}\right)_{i, t-1}$ & $0.193^{* * *}[0.017]$ & $0.205^{* * *}[0.049]$ \\
\hline$\left(F D I_{H i g h-T e c h}^{2}\right)_{i, t-1}$ & $-0.025^{* * *}[0.003]$ & $-0.041 * * *[0.009]$ \\
\hline$\left(F D I_{\text {Low-Tech }}\right)_{i, t-1}$ & $0.055^{* * *}[0.013]$ & $0.259 * * *[0.039]$ \\
\hline$\left(F D I_{\text {Low-Tech }}^{2}\right)_{i, t-1}$ & $-0.010 * * *[0.002]$ & $-0.032 * * *[0.005]$ \\
\hline$\left(\mathbf{W} \cdot F D I_{H i g h-T e c h}\right)_{i, t-1}$ & $0.173 * * *[0.031]$ & $0.170 *[0.092]$ \\
\hline$\left(\mathbf{W} \cdot F D I_{H i g h-T e c h}^{2}\right)_{i, t-1}$ & $-0.029 * * *[0.007]$ & $-0.034 *[0.020]$ \\
\hline$\left(\mathbf{W} \cdot F D I_{L o w-T e c h}\right)_{i, t-1}$ & $0.038[0.025]$ & $0.220 * * *[0.075]$ \\
\hline$\left(\mathbf{W} \cdot F D I_{\text {Low-Tech }}^{2}\right)_{i, t-1}$ & $-0.010 * *[0.004]$ & $-0.042 * * *[0.012]$ \\
\hline \multicolumn{3}{|l|}{ Location Variables } \\
\hline $\ln G R P P C_{i, t-1}$ & $0.040 * * *[0.004]$ & $0.158 * * *[0.013]$ \\
\hline $\ln$ Wage $_{i, t-1}$ & $-0.121 * * *[0.016]$ & $-0.574 * * *[0.059]$ \\
\hline $\ln$ LandSize $_{i, t-1}$ & $0.005[0.005]$ & $0.062 * * *[0.014]$ \\
\hline $\ln T A X P C_{i, t-1}$ & $-0.014[0.009]$ & $0.064 * *[0.028]$ \\
\hline $\ln P O P_{i, t-1}$ & $0.057 * * *[0.016]$ & $0.163 * * *[0.047]$ \\
\hline \multicolumn{3}{|l|}{ Additional Location Variables } \\
\hline In Agglomeration $_{i, t-1}$ & $-0.015[0.017]$ & $-0.0002[0.050]$ \\
\hline $\ln$ Land Price $_{i, t-1}$ & $-0.006[0.004]$ & $-0.017[0.013]$ \\
\hline Constant & $-0.602 * * *[0.084]$ & $-1.950 * * *[0.248]$ \\
\hline Industrial Complex Dummies & Yes & Yes \\
\hline Year Dummies & Yes & Yes \\
\hline$F$-Statistics & $47.92 * * *$ & $48.65 * * *$ \\
\hline $\mathrm{R}^{2}$ & 0.491 & 0.495 \\
\hline
\end{tabular}

Notes. a. $\mathrm{N}=1,166$. b. Significance levels: $* p<0.10, * * p<0.05$, $* * * p<0.01$. c. Numbers in [ ] are standard errors. 